number of Ahnenplasmas varies from species to species; (2) that the number in the combination and not the character of the Ahnenplasmas determines the species. And as there is not a particle of evidence for the latter postulate, we may say that on hypothesis $B$ the theory breaks down by its non-conformity with the facts.

We have then the clilemma, from which I see no escape, that the theorv is inconsistent, on $A$ with itself, on $B$ with the facts. When once worked out and fairly put into words, which was not so easy as it may appear, this argument seemed so obvious that I felt sure it must have been long since urged, confuted, and dismissed. But not having found any refererce to it, I now state it fully, in the hope that the question raised may be thoroughly discussed.

Dublin, October $\mathbf{I} 2$.

\section{Rain-making Experiments.}

YoUR last number contains an article by Prof. Curtis on the "rain-making" experiments in Texas, in which no reference is made to the report published in the October number of the North American Review by General Dyrenforth, who directed the operations. I wish to call attention to the remarkable differences which exist betw een the statements of Prof. Curtis, the meteorologist of the expedition, and General Dyrenforth, its director. On August 10, Prof. Curtis, who had not yet arrived at the scene of the experiments, believes that only sharp showers or "good grass-rain" fell; General Dyrenforth says the amount was nearly 2 inches. On August 18 , Prof. Curtis says that only 0 .02 inch of rain fell ; General Dyrenforth says that "drenching rain fell in torrents for two and a half hours," and that driving from the encampment to Midland, a distance of 25 miles, the road traversed was covered for 6 or 8 miles under 4 to 40 inches of water. It is impossible, under these circumstances, for those interested to come to any conclusion at present with regard to the actual results of the experiments. May I draw your attention further to an article which appeared in the Manchester Guardian of the 1 $3^{\text {th }}$ inst, in which a suggestion was made precisely similar to that put forward by Prof. Giglioli in your last number. If, as seems probable, the experiments of $\mathrm{Mr}$. Aitken amply suffice to explain any positive results obtained, it is evident that the explosions of hydrogen and oxygen, on which General Dyrenforth relies so much, are useless, and that the smoke-producing rackarock does all the work. In an extremely sceptical and very justly critical article, which follows that of General Dyrenforth in the North American Review, Prof. Simon Newcomb, while scouting the "concussion" theories of General Dyrenforth, says, indeed, that smoke particles may possibly serve as nuclei for the condensation of water vapour; but he is evidently unacquainted with the remarkable work of Mr. Aitken, which throws so much light on the matter.

Manchester, October 24

\section{A Rare Phenomenon.}

Having just returned from Norway, it may be of interest to record that the band of light which was observed by many of your correspondents on September II, was remarkably brilliant in N. lat. $62^{\circ}$, extending from the horizon to the zenith, but not beyond. It was nearly, but not quite, equal in width throughout the $90^{\circ}$, and therefore must either have been much wider at the base than at the apex, or else at an immense altitude. Some clue to the estimation of this altitude would be afforded by an accurate record of the zenith distance as observed in England.

I may add that the aurora borealis was distinctly visible in the north and north-west at the same time, but this band rose from the north-east, which led me to conjecture that it might belong to a comet; however, on the following night it did not recur, and I then thought it might have been caused by sonse sun-lit cirri at a great elevation, but it is now obvious that this was not the case. The remarkable feature was its concurrence with, and yet apparent difference from, the ordinary aurora.

Richrond, Surrey, October 24.

W. DUPPA-CROTCH.

The phenomenon observed by Dr. Copeland (Nature, September 24, p. 494) at 11.18 p.m. on September 10 at Dunecht, by Mr. W. E. Wilson at 9 p.m. on September II in Co. Westmeath, and by other observers on the inth in NO. I I 48 , VOL. 44$]$ several parts of England, was observed by a party of three, including myself, at $9.30 \mathrm{p.m}$. on September 25 at Ballater, Aberdeenshire.

It appeared as an inten e white beam of light stretching from east to west and directly overhead, of uniform width and perfectly steady. It seemed quite low down, almost as if it might light up the summit of the church spire were it moved a little further towards the south. At II.3O the light had become diffuse, and it appeared at a much greater elevation, though maintaining its general direction from east to west.

October 23

W. N. Hartley.

\section{Earthquake at Bournemouth}

WE had a sharp momentary shock of earthquake here at four o'clock this afternoon. I happened to have my eyes fixed on a plant with long variegated leaves on my dining-room table. Suddenly there was a heavy sound as of some subterranean fall, and simultaneously the leaves of this plant were violently agitated-waved up and down-for some seconds. It was as if it had risen vertically and then fallen. It was wholly unmoved by so much as a tremor the rest of the afternoon. I tried to reproduce anything like the same disturbance by hand, but without success.

Bregner, Bournemouth, October 25 .

$$
\mathbf{W}=\mathbf{M} g
$$

I HAD read Mr. Slate's letter (NATURE, vol. xliv. p. 445), and admired it ; moreover, I found myself in agreement with him. But it seems to me strange that Prof. Greenhill should approve of it. For Mr. Slate takes as his gravitational unit of force "the weight of one pound under circumstances specified . . (locality, vacuum)." Surely this implies that he agrees with the theorists (Prof. Greenhill's foes) when they say that "the weight of a given body depends on the local value of $g$. " Prof. Greenhill, on the contrary, speaking of goods, says that "the zeight cannot be said to vary with the local valut of $g$ " (NATURE, vol. xliv. p. 493), I would ask him, then-

(I) What name does he give to the earth's pull on a given body? Or, what is it that a spring balance measures when the said body is hung from it? He cannot say "its weight"; for the pull referred to varies with $g$, while Prof. Greenhill's "weight" does not. I conclude that he has no special name for it. The theorists have ; and they thereby gain in brevity without losing by ambiguity, since they do not employ the word "weight" in any other sense in their text-books.

I would also repeat the still unanswered question-(2) How does Prof. Greenhill give the expression for hydrostatic pressure at a given depth in any locality, if he banishes " $g$ "? (Nature, vol. xliv. p. 34I). And does he conclude that Mr. Slate does not use " $g$ " in hydrostatics?

Again . . . (3) Does Prof. Greenhill, in common with Mr. Slate and the theorists, use the word mass in speaking of the fundamental units; and, if so, in what sense?

In the science of dynamics we rec ognize two properties of matter : . . . (i.) its inertia ; . . . (ii.) the attraction between it and other matter. The theorists use the word mass when they refer to quantity of matter as measured by its inertia; and they use the word weight when they refer to the attraction of a given body to the earth. For commercial purposes it is convenient to measure quantity of matter by balancing its weight against that of the standard lump of platinum, its multiples, and sub-multiples. Hence the every-day, slightly ambiguous, use of the word "weight" in matters in which we are not concerned with inertia. But in the science of dynamics, of which Newton's laws are the foundation, we are concerned primarily with inertia. The theorists, therefore, in their text-books, regard the well-known lump of platinum as the standard pound, the British unit of mass. They thus have the word "weight" free, and say (e.g.) that the zecight of the stondard pound is measured by the resultant pressure that it exirts (in vacuo) on the bottom of the box in which it lies. It requires more than general expressions of condemnation to show that any other system of nomenclature is clearer or less free from ambiguity, or that the equation $\mathrm{W}=\mathrm{M} g$ has not as much meaning as any other dynamical equation. (I may refer back to my letter, NATURE, vol. xliv. p. 493).

Devonport, September 26. 